\title{
Dentists to run marathon to support struggling colleagues
}



Ronan Lee

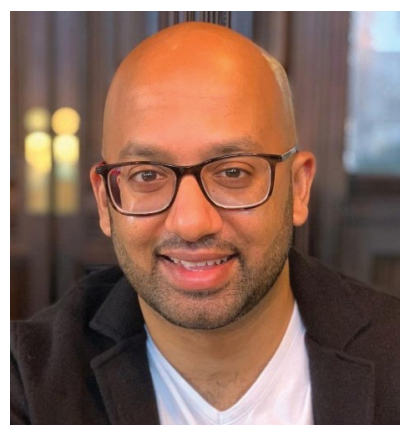

Zayd Rawoot

On 3 October 2021, four runners will be taking part in the London Marathon 2021 to fundraise for the BDA Benevolent Fund. Ronan Lee, Zayd Rawoot and Helen Reddington will be completing the marathon virtually and Robert Chaffe will be running in person.

Fifty thousand people will be running the streets of London for this year's marathon and another 50,000 will take part in the event virtually, from wherever they are in the country, completing the marathon over 24 hours and choosing their own route.

Ronan Lee is a dental student at King's College London. He commented: 'I took up running during the first lockdown, and made it my goal to run a marathon having become a keen member of Strava. Having run my own half marathons, this is my first official race, and I am very grateful to the BDA Benevolent Fund for giving me this opportunity.

'This amazing charity helps dental students, dentists and their dependants in the UK who suffer financial hardship. Dentistry is a huge part of my life, and it is so rewarding being able to help others who may be struggling in our profession.'

Dentist Zayd Rawoot said: 'I have always had a keen interest in helping those less fortunate than myself and I have always endeavoured to achieve this goal. I'm very passionate about dentistry and I really enjoy my role as a GDP. I feel it is imperative to support my fellow colleagues who are struggling.

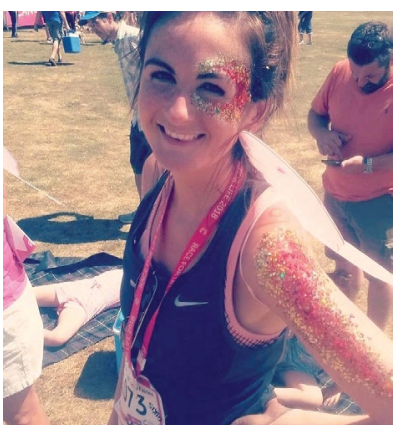

Helen Reddington

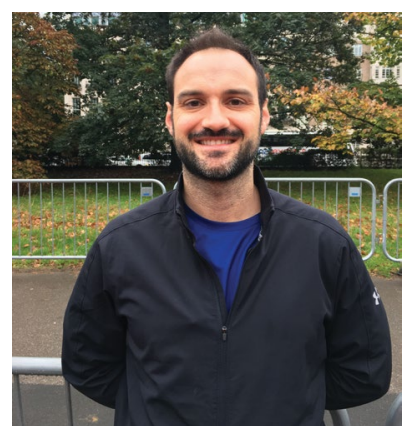

Robert Chaffe
'I love to keep fit through regular exercise including swimming, biking/ cycling, walking/hiking, running and football, all of which enable me to escape the stresses of life! However, I look forward to the amazing challenge which lies ahead for what would be my first ever marathon! I have previously completed sponsored bike rides, including the London to Paris bike ride a number of years ago, participated in several charity football and other sporting events. I hope to also be completing a "Mighty Hike" challenge this summer in the Lake District which I believe will also stand me in good stead for the virtual London Marathon!'

Dr Helen Reddington works at a practice in Southwell, Nottingham. Helen said: 'I feel lucky to be in a job that I enjoy. I have a lovely patient base and get on well with my dental team. I was really honoured when I was contacted by the BDA Benevolent fund with an offer of a charity place in the virtual London Marathon 2021. It has been a hard few months for our dental profession and this year more than ever I have tried hard to keep on top of my mental and physical health. Running has always been something that I enjoy and has been a great way of achieving this'.

Dentist Robert Chaffe from London has been training and fundraising for the BDA Benevolent Fund since spring 2020 and will be running the London Marathon in person this October.

For more information and to sponsor the runners, visit https://www. bdabenevolentfund.org.uk/supportus/london-marathon/.

\section{Scottish Government 'must apply full pay award to dentists'}

Earlier in August, the British Dental Association (BDA) called on the Scottish Government to confirm that the recently announced $3 \%$ pay award for dentists will be applied to practitioners' overall remuneration package to avoid frontline staff potentially being left out of pocket and practices struggling to invest to improve care.

Historically in Scotland, the recommended uplift has not applied to all dentists' allowances and payments, meaning the overall awards often fall short of the pay review body's recommendations.

Last year, the Scottish Government did not apply the recommended $2.8 \%$ uplift to practice allowances - which make up around $16 \%$ of practice income - leaving an overall increase of less than the review body's recommendations. The BDA estimates that the net award for that year was around $2.3 \%$.

While one-off support to fund improvements in ventilation has been offered by the Scottish Government, NHS dentists do not routinely receive capital investment. These earnings serve to fund all improvements in equipment, training and facilities for NHS practices.

Scottish Government officials have stated they will provide details of how the package will operate in due course. The BDA is calling for the $3 \%$ uplift to be applied to the full remuneration package.

David McColl, Chair of the BDA's Scottish Dental Practice Committee, said: 'The Scottish Government's announcement has left key questions unanswered.

'This uplift will do little to correct a decade of austerity, and not all of this increase may actually reach dentists, who rely on their earnings to invest in their practices.

'In the recent election, Ministers put dentistry front and centre in their pitch for government. If they are going to deliver on their promises they shouldn't be short-changing frontline practitioners.' 